\title{
Comparative study of operated cases of peptic ulcer in Madras in the 1940s and 1960s ${ }^{1}$
}

\author{
N. MADANAGOPALAN, R. SUBRAMANIAM, AND M. N. KRISHNAN \\ From Madras Medical College and the Government General Hospital, Madras, India
}

The literature, and particularly the statistical evaluation of peptic ulcer, is vast and ordinarily there should be little excuse for adding to it, unless one has some definite reason. It is well recognized that all over the world this disease pattern in the last few decades has undergone certain changes with regard to the duodenal-gastric ulcer ratio, sex incidence, and the occurrence of complications. Bradfield (1927) and Dogra (1940a and b) have already presented the incidence of various types of peptic ulcers observed in Madras up to the year 1940.

We have now chosen to compare the patients who have come for surgery at the Government General Hospital, Madras (1,200 cases) in the last four years with a similar number about 20 years ago. A detailed study was made from the actual case sheets and operation notes and not from any compilation of hospital statistics. Incidentally this should serve to record the pattern of the disease, as met on the operation table at the Government General Hospital, since the era of Bradfield and Dogra.

The cases, depending on the site of ulcer, are labelled as duodenal ulcer, ulcer in the body of stomach, ulcer in the pylorus, and combined gastric and duodenal ulcer. Though pyloric ulcer is really a gastric ulcer, it is grouped separately because some authors have not included it in the group of gastric ulcer. But in the final compilation of data in this paper, it will be treated as gastric ulcer. The causes of admission for surgery are considered under four

'Paper read at the 7th Annual Conference of the Indian Society of Gastroenterology held at Bombay during September 1966. headings: (1) periodic pain with or without vomiting but without clinical evidence of obstruction; (2) pyloric stenosis with clinical evidence of obstruction in the form of visible gastric peristalsis; (3) perforation; (4) massive bleeding.

\section{INCIDENCE OF DUODENAL AND GASTRIC ULCERS}

The overall distribution of the site of ulcers during the period 1942-45 and 1962-66 is presented in Table I.

The ratio of duodenal to gastric ulcer confined to the body of the stomach was 15.9:1 two decades ago compared with $15 \cdot 2: 1$ during the last four years, and, when pyloric ulcer is also included in the gastric ulcer group, the ratios are 8.7:1 and 7.3:1 respectively.

The ratios given by other authors are Bradfield (1927), for Madras, $12 \cdot 1: 1$; Somervell (1927), for Travancore, 36.7:1; Rao (1938), for Visakhapatnam, 6.5:1; Dogra (1940a), for Madras, 48:1; and for South India 30:1 (1940b); Chatterjee, Das, and Sengupta (1958), for Calcutta, 11.1:1; and Raghavan (1962), for Bombay, 6.4:1. The ratio observed is considerably lower than those reported by Dogra and significantly less than those of Bradfield, earlier from Madras. However, it must be pointed out that Dogra did not include pyloric ulcers in his group of 'gastric ulcers'.

\section{SEX INCIDENCE}

Forty-four of 1,200 cases were women in the 1942-45 group compared with 93 of 1,200 in 1962-66, giving

TABLE I

INCIDENCE AND SEX DISTRIBUTION OF DUODENAL AND GASTRIC ULCER

\begin{tabular}{|c|c|c|c|c|c|c|}
\hline \multirow[t]{2}{*}{ Ulcer Type } & \multicolumn{3}{|l|}{$1942-45$} & \multicolumn{3}{|c|}{$1962-66$} \\
\hline & Male & Female & Total & Male & Female & Total \\
\hline $\begin{array}{l}\text { Duodenal } \\
\text { Gastric } \\
\text { Pyloric } \\
\text { Combined } \\
\text { Total } \\
\text { Male: Female } \\
\text { Duodenal to gastric } \\
\text { Duodenal: gastric + pyloric }\end{array}$ & $\begin{array}{r}1,008 \\
63 \\
53 \\
32 \\
1,156 \\
26 \cdot 3: 1 \\
15 \cdot 9: 1 \\
8 \cdot 7: 1\end{array}$ & $\begin{array}{r}39 \\
3 \\
2 \\
-44\end{array}$ & $\begin{array}{r}1,047 \\
66 \\
55 \\
32 \\
1,200\end{array}$ & $\begin{array}{r}956 \\
61 \\
66 \\
24 \\
1,107 \\
11 \\
15 \\
7\end{array}$ & $\begin{array}{r}78 \\
7 \\
7 \\
1 \\
93\end{array}$ & $\begin{array}{r}1,034 \\
68 \\
73 \\
25 \\
1,200\end{array}$ \\
\hline
\end{tabular}


an overall ratio of men to women as $26 \cdot 3: 1$ and 11.9:1 respectively. Although Dogra has concluded that the incidence is one woman to 18 men for the total number of cases studied in South India, only 34 of 1,099 cases collected from the General Hospital, Madras, were in women, the male to female ratio being $31: 1$.

\section{DISTRIBUTION OF VARIOUS TYPES OF ULCER WITH REFERENCE TO BASIC SYMPTOMS AND SEX}

It will be seen from Table II and Fig. 1, that the number of women operated in all the groups, pain \pm vomiting, visible gastric peristalsis, and perforation, has shown a significant increase in the last two decades, reducing the male and female ratio in each group. Further it is also observed that the number of cases operated for perforation has considerably increased from 68 to 158 . Of cases operated two decades ago, $51 \cdot 3 \%$ had clinical evidence of pyloric stenosis while $55.4 \%$ operated in the last few years did not have visible gastric peristalsis and only $30.7 \%$ operated had that sign. Massive alimentary bleeding has been the cause for surgery in nine cases in the last four years while no case had been operated on for that complaint as such two decades ago. Somervell and Orr (1936) felt that haemorrhage and perforation were rare in South West India, as they saw only four cases of perforation in 2,500 cases of duodenal ulcer, and no actual figures were given for cases of haemorrhage. While massive haemorrhage requiring surgery is still fairly uncommon, that can no longer be said for perforation. Though only $5.6 \%$ of cases were admitted for perforation in 1942-45, $13.2 \%$ of cases presented with perforation during the period 1962-66. Raghavan (1962) found in Bombay that the incidence of perforation in duodenal ulcer and gastric ulcers showed no significant difference. In the 1962-66 series, $13.6 \%$ of cases with duodenal ulcer and $14.1 \%$ of cases of gastric ulcer

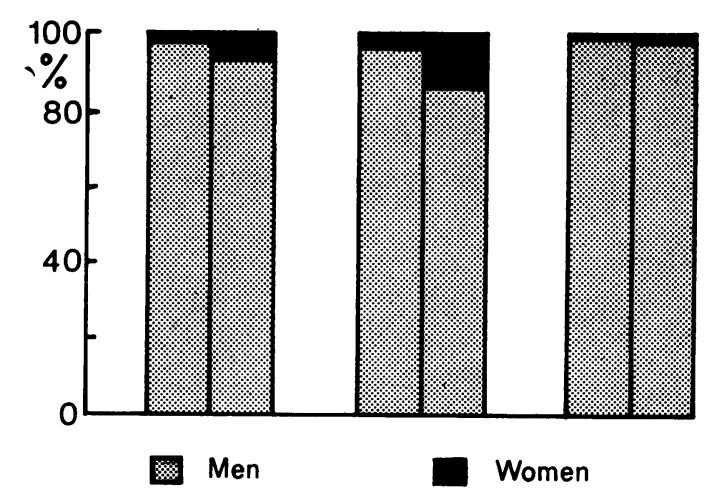

\begin{tabular}{|c|c|c|c|c|c|c|c|c|c|c|c|}
\hline \multirow{2}{*}{\multicolumn{2}{|c|}{$\begin{array}{l}\text { Pain } \pm \\
\text { Vomiting } \\
1942-45\end{array}$}} & \multirow{2}{*}{\multicolumn{2}{|c|}{$1962-66$}} & \multicolumn{4}{|c|}{$\begin{array}{l}\text { Visible Gastric } \\
\text { Peristalis }\end{array}$} & \multicolumn{4}{|c|}{ Perforation } \\
\hline & & & & 1942 & -45 & 1962 & $2-66$ & 1942 & -45 & 1962 & -66 \\
\hline $\begin{array}{l}M \\
501 \\
96.9\end{array}$ & $\begin{array}{l}F \\
16 \\
3 \cdot 1\end{array}$ & $\begin{array}{l}M \\
624 \\
93 \cdot 8\end{array}$ & $\begin{array}{l}F \\
41 \\
6 \cdot 2 \%\end{array}$ & $\begin{array}{l}M \\
588 \\
95 \cdot 6\end{array}$ & $\begin{array}{l}F \\
27 \\
4 \cdot 4\end{array}$ & $\begin{array}{l}M \\
320 \\
87\end{array}$ & $\begin{array}{l}F \\
48 \\
13 \%\end{array}$ & $\begin{array}{l}M \\
67 \\
98 \cdot 5\end{array}$ & $\begin{array}{l}F \\
1 \\
1 \cdot 5\end{array}$ & $\begin{array}{l}M \\
154 \\
97 \cdot 5\end{array}$ & $\begin{array}{l}F \\
4 \\
2 \cdot 5 \%\end{array}$ \\
\hline
\end{tabular}

FIG. 1. Diagram showing the increased incidence in women of peptic ulcer in 1962-66 in all 'symptom groups'.

were admitted for perforation, the difference being insignificant, though in the $1942-45$ series $5.3 \%$ of cases of duodenal ulcer and $8.5 \%$ of those of gastric ulcer were admitted for perforation.

The maximum number of cases operated in both groups fall in the age group 26 to 35 . Of cases operated two decades ago, $59.9 \%$ and $56.4 \%$ of cases operated in the last four years were below the age of 35 , and $86.6 \%$ and $82.3 \%$ is the percentage of cases below the age of 45 . As regards women, only $9 \%$ in the $1942-45$ series and $13.3 \%$ in the $1962-66$ series were below the age of 25 as against $22.3 \%$ and $21.3 \%$ in men.

TABLE II

\begin{tabular}{|c|c|c|c|c|c|c|c|c|c|}
\hline \multirow{3}{*}{ Ulcer } & \multirow{3}{*}{$\begin{array}{l}\text { DISTR } \\
\text { Period }\end{array}$} & $\mathrm{s}$ & FEREN & O BAS & MPT & ND SE & & \multirow{2}{*}{\multicolumn{2}{|c|}{ Eleeding }} \\
\hline & & \multicolumn{2}{|c|}{ Pain \pm Vomiting } & \multicolumn{2}{|c|}{$\begin{array}{l}\text { Visible Gastric } \\
\text { Peristalsis }\end{array}$} & \multicolumn{2}{|c|}{ Perforation } & & \\
\hline & & $\boldsymbol{M}$ & $F$ & $\boldsymbol{M}$ & $\boldsymbol{F}$ & $M$ & $\boldsymbol{F}$ & $\boldsymbol{M}$ & $\boldsymbol{F}$ \\
\hline \multirow[t]{2}{*}{ Duodenal } & $1942-45$ & 422 & 14 & 531 & 24 & 55 & 1 & $\mathbf{0}$ & $\mathbf{0}$ \\
\hline & $1962-66$ & 544 & 34 & 267 & 41 & 138 & 3 & 7 & 0 \\
\hline \multirow[t]{2}{*}{ Gastric } & $1942-45$ & 36 & 1 & 20 & 2 & 7 & 0 & 0 & 0 \\
\hline & $1962-66$ & 38 & 6 & 15 & $\overline{1}$ & 8 & $\mathbf{0}$ & 0 & o \\
\hline \multirow{2}{*}{ Pyloric } & $1942-45$ & 28 & 1 & 20 & 1 & 5 & 0 & 0 & 0 \\
\hline & $1962-66$ & 31 & 1 & 26 & 5 & 8 & 1 & 1 & 1 \\
\hline \multirow[t]{2}{*}{ Combined gastric and duodenal } & $1942-45$ & 15 & 0 & 17 & $\mathbf{0}$ & $\mathbf{0}$ & $\mathbf{0}$ & 0 & o \\
\hline & $1962-66$ & 11 & 0 & 12 & 1 & $\mathbf{0}$ & $\mathbf{0}$ & 1 & 0 \\
\hline Total & $\begin{array}{l}1942-45 \\
1962-66\end{array}$ & $\begin{array}{l}501 \\
624\end{array}$ & $\begin{array}{l}16 \\
41\end{array}$ & $\begin{array}{l}588 \\
320\end{array}$ & $\begin{array}{l}27 \\
48\end{array}$ & $\begin{array}{r}67 \\
154\end{array}$ & $\begin{array}{l}1 \\
4\end{array}$ & $\begin{array}{l}0 \\
9\end{array}$ & $\begin{array}{l}\mathbf{0} \\
\mathbf{0}\end{array}$ \\
\hline Ratio & $\begin{array}{l}1942-45 \\
1962-66\end{array}$ & $\begin{array}{l}31 \cdot 3 \\
15 \cdot 2\end{array}$ & & $\begin{array}{l}21 \cdot 8 \\
6 \cdot 7:\end{array}$ & & $\begin{array}{r}67: 1 \\
38 \cdot 7: 1\end{array}$ & & & \\
\hline
\end{tabular}


DURATION OF SYMPTOMS BEFORE ADMISSION

Excluding cases of perforation, information could be obtained from the records about the duration of symptoms before admission in 1,096 cases during the period 1942-45 and in 1,013 cases for the period 196266. They are presented in Table III and Fig. 2, classified according to the main symptom and type of ulcer seen.

Of cases in the $1942-45$ series, $73.7 \%$ and $80.7 \%$ of cases in 1962-66 had symptoms up to five years before surgery was undertaken. While the number of cases with visible gastric peristalsis was greater in the 1942-45 period, cases presenting with pain with or without vomiting outnumbered those with visible gastric peristalsis in 1962-66.

\section{BLOOD GROUPS}

ABO blood grouping was done only in an insignificant number of cases during 1942-45 and hence is not taken into consideration. Particulars about blood groups were available from case records in 1,058 cases for the period 1962-66. Table IV shows the distribution in various types of ulcer and between sexes, compared with the normal control for the hospital.

The same information is presented as a percentage occurrence as well as a percentage increase or decrease over controls in Table $\mathrm{V}$.

The incidence of both duodenal and gastric ulcer is greater than the control with blood group $\mathbf{O}$, while the incidence of both duodenal and gastric
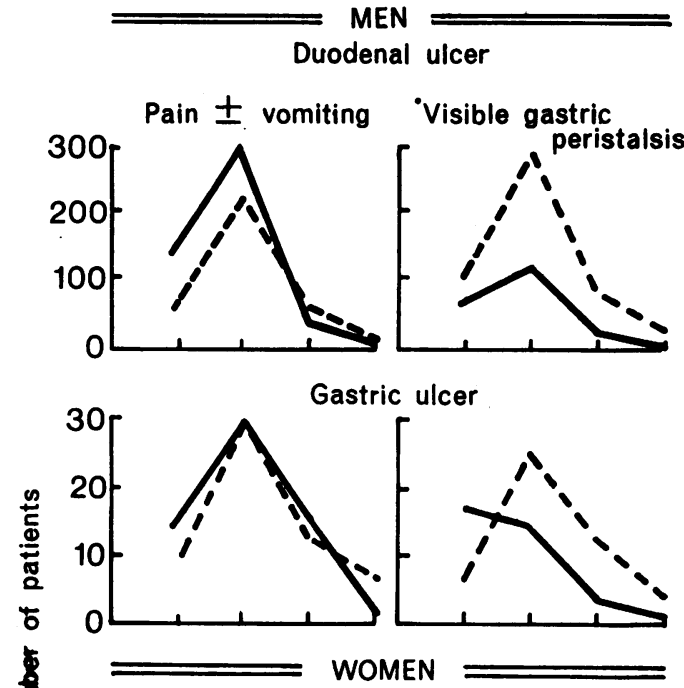

Duodenal ulcer
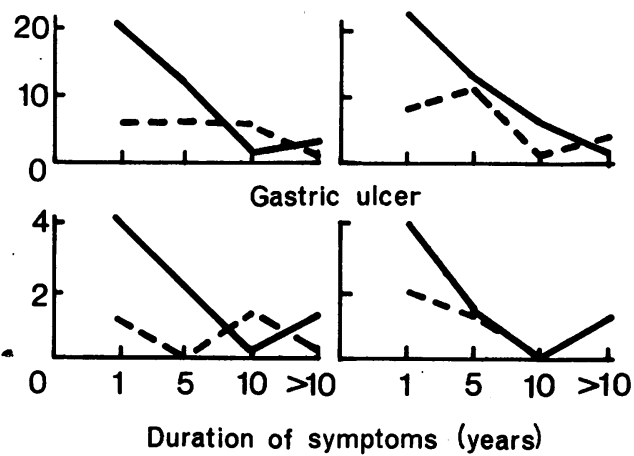

FIG. 2. Duration of symptoms before admission in 1942-45 (broken lines) and 1963-66 (solid lines).

TABLE III

DURATION OF SYMPTOMS

Duration in Years

Male

\begin{tabular}{llll}
\hline Pain \pm Vomiting & \multicolumn{2}{l}{ Visible } & Gastric Peristalsis \\
$1962-66$ & $1942-45$ & $1962-66$
\end{tabular}

Duodenal Ulcer

1

$1 \cdot 1$ to 5

$5 \cdot 1$ to 10

Above 10

Gastric Ulcer

1

$1 \cdot 1$ to 5

$5 \cdot 1$ to 10

Above 10

Pyloric Ulcer

1. 1 to 5

$5 \cdot 1$ to 10

Above 10

Combined Gastric and

Duodenal Ulcer

1.1 to

$5 \cdot 1$ to 10

Above 10

$\begin{array}{rr}81 & 157 \\ 211 & 27 \\ 91 & 74 \\ 26 & 26 \\ & \\ 8 & 12 \\ 15 & 14 \\ 7 & 1 \\ 4 & \\ 2 & 18 \\ 17 & \\ 6 & \\ 3 & \end{array}$

\section{7}

274
74

26

12
14
11

5
18
4
4

111
287
87
29

3
12
6
0

3
12
6
0

3
12
6
0

94
119
33
20
8
5
2
0
10
11
3

3
4
5
1

Female

\begin{tabular}{lllll}
\hline Pain \pm & Vomiting & & \multicolumn{2}{l}{ Visible Gastric Peristalsis } \\
& $1962-66$ & & $1942-45$ & $1962-66$
\end{tabular}

5
0
3
1
1
0
0
0
0
0

5
5
3
0

20
12
1
1

8
11
1
2

22
12
6
1

1
0
1
0


TABLE IV

BLOOD GROUP DISTRIBUTION

\begin{tabular}{|c|c|c|c|c|c|c|c|c|c|}
\hline \multirow{3}{*}{ Type of Ulcer } & \multicolumn{8}{|c|}{ Blood Group (No. of Cases) } & \multirow[t]{3}{*}{ Total } \\
\hline & \multicolumn{2}{|l|}{$O$} & \multicolumn{2}{|l|}{$A$} & \multicolumn{2}{|l|}{$\boldsymbol{B}$} & \multicolumn{2}{|c|}{$\boldsymbol{A B}$} & \\
\hline & $M$ & $F$ & $M$ & $\boldsymbol{F}$ & $M$ & $F$ & $M$ & $F$ & \\
\hline $\begin{array}{l}\text { Duodenal } \\
\text { Gastric } \\
\text { Pyloric } \\
\text { Combined gastric and duodenal } \\
\text { Control ( } 5,000 \text { cases of Raghavan) }\end{array}$ & $\begin{array}{l}437 \\
26 \\
26 \\
11 \\
41 \cdot 2 \%\end{array}$ & $\begin{array}{r}32 \\
4 \\
2 \\
1\end{array}$ & $\begin{array}{r}144 \\
9 \\
10 \\
3 \\
21 \cdot 2\end{array}$ & $\begin{array}{r}16 \\
0 \\
1 \\
0\end{array}$ & $\begin{array}{r}224 \\
14 \\
20 \\
6 \\
32 \cdot 0\end{array}$ & $\begin{array}{r}20 \\
2 \\
4 \\
0\end{array}$ & $\begin{array}{r}34 \\
3 \\
2 \\
2 \\
5\end{array}$ & $\begin{array}{l}4 \\
1 \\
0 \\
0\end{array}$ & $\begin{array}{r}911 \\
59 \\
65 \\
23\end{array}$ \\
\hline
\end{tabular}

TABLE V

PERCENTAGE INCREASE OR DECREASE IN BLOOD GROUP DISTRIBUTION OVER CONTROL

\begin{tabular}{|c|c|c|c|c|c|}
\hline \multirow[t]{2}{*}{ Blood Group } & \multirow[t]{2}{*}{ Control } & \multicolumn{2}{|c|}{ Duodenal Ulcer } & \multicolumn{2}{|c|}{ Gastric Ulcer } \\
\hline & & $\begin{array}{l}\text { Disease } \\
(\%)\end{array}$ & $\begin{array}{l}\text { Percentage of Increase } \\
\text { or Decrease on Control }\end{array}$ & $\begin{array}{l}\text { Disease } \\
(\%)\end{array}$ & $\begin{array}{l}\text { Percentage of Increase } \\
\text { or Decrease on Control }\end{array}$ \\
\hline $\begin{array}{l}\text { O } \\
\text { A } \\
\text { B } \\
\text { AB }\end{array}$ & $\begin{array}{r}41 \cdot 2 \\
21 \cdot 3 \\
32 \cdot 0 \\
5 \cdot 5\end{array}$ & $\begin{array}{r}51 \cdot 5 \\
17 \cdot 5 \\
26 \cdot 7 \\
4 \cdot 3\end{array}$ & $\begin{array}{l}+25 \\
-17.84 \\
-16.56 \\
-21.8\end{array}$ & $\begin{array}{r}46 \cdot 8 \\
16 \cdot 1 \\
32 \cdot 2 \\
4 \cdot 9\end{array}$ & $\begin{array}{l}+13.6 \\
-24.4 \\
+0.625 \\
-10.91\end{array}$ \\
\hline
\end{tabular}

TABLE VI

LOCALIZATION OF GASTRIC ULCER IN COMBINED GASTRIC AND DUODENAL GROUP AND SEX INCIDENCE

\begin{tabular}{|c|c|c|c|c|c|c|c|c|}
\hline \multirow[t]{3}{*}{ Period of Study } & \multirow[t]{3}{*}{ Total } & \multirow[t]{3}{*}{$M$} & \multirow[t]{3}{*}{$F$} & \multicolumn{4}{|c|}{ Site of Gastric Ulcer } & \multirow{3}{*}{$\begin{array}{l}\text { Percentage of } \\
\text { Combined Group } \\
\text { to Total Studied } \\
(1,200)\end{array}$} \\
\hline & & & & \multirow[t]{2}{*}{ Pylorus } & \multicolumn{2}{|c|}{ Lesser Curvature } & \multirow{2}{*}{$\begin{array}{l}\text { Body of } \\
\text { Stomach }\end{array}$} & \\
\hline & & & & & Middle $\frac{1}{8}$ & Upper $\frac{1}{8}$ & & \\
\hline $\begin{array}{l}1942-45 \\
1962-66\end{array}$ & $\begin{array}{l}32 \\
25\end{array}$ & $\begin{array}{l}32 \\
24\end{array}$ & $\begin{array}{l}0 \\
1\end{array}$ & $\begin{array}{l}5 \\
3\end{array}$ & $\begin{array}{l}24 \\
17\end{array}$ & $\begin{array}{l}3 \\
2\end{array}$ & $\begin{array}{l}0 \\
3\end{array}$ & $\begin{array}{l}2 \cdot 7 \\
2 \cdot 1\end{array}$ \\
\hline
\end{tabular}

TABLE VII

MODE OF PRESENTATION OF COMBINED GASTRIC AND DUODENAL ULCER

\begin{tabular}{|c|c|c|c|c|c|}
\hline Period of Study & $\begin{array}{l}\text { Pain } \pm \\
\text { Vomiting }\end{array}$ & $\begin{array}{l}\text { Visible } \\
\text { Gastric } \\
\text { Peristalsis }\end{array}$ & Perforation & $\begin{array}{l}\text { Haemorrhage as } \\
\text { Main Cause }\end{array}$ & Total \\
\hline $1942-45$ & $\begin{array}{l}15 \\
46.9 \%\end{array}$ & $\begin{array}{l}17 \\
53 \cdot 1 \%\end{array}$ & 0 & 0 & 32 \\
\hline $1962-66$ & $\begin{array}{l}10 \\
40 \%\end{array}$ & $\begin{array}{l}14 \\
56 \%\end{array}$ & 0 & $\begin{array}{l}1 \\
4 \%\end{array}$ & $\begin{array}{l}25 \\
100 \%\end{array}$ \\
\hline
\end{tabular}

ulcer is considerably less than the control in blood group A. While being in blood group B might also offer some protection against duodenal ulcer, this does not hold true for gastric ulcer. These have been found statistically significant. As this information is from operated cases only, it cannot be said with certainty that it will also reflect the blood group distribution of peptic ulcer in the population.

\section{COMBINED GASTRIC AND DUODENAL ULCER}

In this study, the pyloric ulcers are grouped with ulcers in the body of the stomach. The figures obtained for the period 1942-45 and 1962-66 are presented in Table VI.
The mode of presentation of cases with combined gastric and duodenal ulcer studied is given in Table VII. The incidence among the cases of peptic ulcer studied by other authors is Wilkie (1926) $14 \%$; Johnson (1956) 9.2\%; Dogra (1940b) 7\%; Mangold (1958) $3.5 \%$; and Raghavan (1962) $1.2 \%$.

There is only one female among the 55 cases in this series and no case of combined ulcer presented with perforation.

\section{DISCUSSION}

The data on the ratio of duodenal to gastric ulcer, sex incidence, blood group studies, and behaviour pattern of peptic ulcer in any particular place and 
race available from out-patient study, clinical evaluation, the routine pictures usually available in the radiological departments are all subject to gross errors and hence unsuitable for statistical evaluation of the problems in peptic ulcer. As the number of cases coming to necropsy still continues to be low, it will not be of help in this study. The only objective method of conclusively detecting the presence of and site of peptic ulcer in our hospital is the findings at laparotomy. We have chosen to compare 1,200 cases admitted during the period $1942-45$ with a similar number for the last four years. The total period from 1942 to 1966 was not taken as it would be too long and we felt that useful information might be gathered by studying and comparing cases with a time interval of about 20 years between them. While for every operated case of peptic ulcer there could be any number of non-operated cases, this may not truly represent the actual picture of the whole peptic ulcer population, but it should be helpful to study the common symptoms and complications that force a patient to be admitted to hospital and submit to surgery.

The duodenal to gastric ulcer ratio over the last two decades has shown a definite change from that presented by Dogra (1940a and b), Bradfield (1927), and Somervell (1927) in the past and seems to be nearer to that presented by Rao (1938) and Raghavan (1962).

The male to female ratio, however, is still much higher than that quoted by Avery Jones and Gummer (1961) as 4:1, and has shown considerable change of late. From being $31: 1$ in the General Hospital from Dogra's figures for the period 1929-39, it has changed to $26 \cdot 3: 1$ in $1942-45$ and to $11 \cdot 9: 1$ in 1962-66. Raghavan felt that the comparatively sheltered existence, the feeling of security and protection incidental to the type of family life here, and probably repeated pregnancies contributing an additonal protection may all play an important part in the rarity of ulcers amongst women in India. However, the figures for the year 1962-66 for women is alarming in that the incidence of peptic ulcer requiring surgery is very much on the increase and probably could catch up with the present western figures in the near future. Possibly it may have some bearing on the visible change in the social and emotional outlook of Indian women today. They no longer lead a sheltered existence and they try to catch up with men in many fields but probably at the expense of losing the protection against peptic ulcer they enjoyed a few decades ago.

Somervell and Orr (1936) opined that haemorrhage and perforation were rare in South West India. They observed only four cases of perforation in 2,500 cases. However, Raghavan had observed that nearly one-fourth of duodenal as well as gastric ulcer patients studied in Bombay during the period 1931-56 were admitted for perforation, and the incidence of perforation in duodenal and gastric ulcer cases shows no significant difference. The statement of Somervell and Orr in 1936 can no longer hold true even for Madras today where, although only $5.6 \%$ of cases were admitted for perforation in $1942-45,13.2 \%$ of cases operated in 1962-66 were for perforation. As it is possible that some patients succumb before reaching hospital or are not operated upon due to poor general condition or their unwillingness for surgery, this incidence could really be even higher. Owing to greater prevalence of obstruction rather than perforation in India in the past, Cleave and Campbell (1966), who group peptic ulcers as a saccharine disease, has called them 'sclerotic peptic ulcer of India'. In this connexion it is of great interest to read a statement by them that 'the chronic sclerosing duodenal ulcer, so characteristic of the Indians in the ulcer belt of India, has changed completely in the Indians in Natal. In them acute perforations are a prominent feature of the disease, which is reported to harmonize perfectly with their tenfold greater consumption of sugar'. What role this statement could have on the greater increase of perforation amongst peptic ulcer cases now is worth deep thought. However, it is very evident that people are giving up the customary habit of taking 'cold rice' in favour of coffee and tea. The majority of cases $(51.3 \%)$ operated in $1942-45$ had visible gastric peristalsis while $55.4 \%$ operated in $1962-66$ had only periodic pain with or without vomiting, without visible gastric peristalsis. Over $80 \%$ of cases operated were below the age of 45 , and this probably represents the age of the population at risk.

The ABO blood grouping has shown the incidence amongst operated cases to be higher in $O$ and less in A compared with normal distribution, which is in agreement with the report by Aird, Bentall, Mehigan, and Roberts (1954) and Clarke, Cowan, Edwards, Howel-Evans, McConnell, Woodrow, and Sheppard (1955) but at vairance with the findings of Raghavan (1962) and Ghosh, Biswas, and Chatterjee (1951).

The incidence of combined gastric and duodenal ulcers $(2.7 \%$ and $2.1 \%)$ is higher than that observed by Raghavan $(1.2 \%)$ but is definitely lower than that reported by western authors. It is found to be uncommon in women here, only one out of the total of 55 (including both groups) being women.

\section{SUMMARY}

We have compared 1,200 operated cases of peptic 
ulcer at the Government General Hospital, Madras, during the period 1942-46 with a similar number for the period 1962-66.

The duodenal to gastric ulcer ratio has changed from 48:1 quoted by Dogra (1940a) and 12:1:1 by Bradfield (1927) to 7.3:1 in 1962-66.

The male to female ratio from being $31: 1$ for the period 1929-38 quoted by Dogra (1940b) has been reduced to $26 \cdot 3: 1$ in $1942-45$ and to $11.9: 1$ in 1962-66.

There is the impression from the literature that peptic ulcer in India follows a chronic stenosing type rather than perforation, but it may no longer be true because, while only four of 2,500 cases studied by Somervell and Orr presented with perforation, $13.2 \%$ of cases operated in 1962-66 presented with perforation.

Though no operated case presented for massive haemorrhage as such during the period 1942-46, nine cases were admitted with that as the presenting symptom during the period 1962-66.

The ABO blood grouping has shown a higher frequency in $O$ and lesser frequency in $A$.

The age incidence, duration of symptoms before seeking admission for operation, and some aspects of combined gastric and duodenal ulcer met with are presented.

We owe our deep gratitude to Mr. R. Kumar, statistician of the General Hospital, who gathered the case records, and for his help in preparing this paper.

We take this opportunity to thank the Dean, the General Hospital and Madras Medical College for granting permission to use the hospital records, and the Director of Medical Education, Madras, for permitting us to present this paper.

\section{REFERENCES}

Aird, I., Bentall, H. H., Mehigan, J. A., and Roberts, J. A. F. (1954) The blood groups in relation to peptic ulceration, carcinoma of colon, rectum, breast, and bronchus: an association between the ABO groups and peptic ulceration. Brit. med. J., 2, 315-321.

Bradfield, E. W. C. (1927). Gastric ulcers in Southern India. In Transactions of the 7th Congress Far Eastern Association of Tropical Medicine. Vol. I, p. 221. Thackers Press and Directories, Calcutta.

Chatterjee, S. C., Das, D. C., and Sengupta, S. N. (1958). Peptic ulcer in poorer communities of West Bengal: Analysis of 100 proved cases. J. Indian med. Ass., 30, 35-43.

Clarke, C. A., Cowan, W. K., Edwards, J. W., Howel-Evans, A. W. McConnell, R. B., Woodrow, J. C., and Sheppard, P. M. (1955). The relationship of ABO blood groups to duodenal and gastric ulceration. Brit. med. J., 2, 643-646.

Cleave, T. L., and Campbell, J. D. (1966). Diabetes, Coronary Thrombosis, and the Saccharine Disease. pp. 93-94. J. Wright, Bristol.

Dogra, J. R. (1940a). Studies on peptic ulcer in South India. I. Introduction and clinical study of 258 cases. Indian J. med. Res., 28, 145-161.

- (1940b). Studies on peptic ulcer in South India. II. A statistical survey. Ibid., 28, 481-507.

Ghosh, M. N., Biswas, B. N., and Chatteriee, M. L. (1957). ABO blood groups and peptic ulcer in Indians. Bull. Calcutta Sch. trop. Med., 5, 169.

Johnson, H. D. (1956). Associated gastric and duodenal ulcers. Surg. Gynec. Obstet., 102, 287-292.

Jones, F. A., and Gummer, J. W. P. (1960). Clinical Gastroenterology, p. 323. Blackwell, Oxford.

Mangold, R. (1958). Combined gastric and duodenal ulceration. Brit. med. J., 2, 1193-1197.

Raghavan, P. (1962). Epidemiology and clinical behaviour of peptic ulcer in Bombay, India. Gastroenterology, 42, 130-143.

Raghavan, T., Medical Officer, Blood Bank, General Hospital. Unpublished data. Personal communication.

Rao, M. N. (1938). Peptic ulcer in northern circars: a note on the incidence. Indian med. Gaz., 73, 454-457.

Somervell, T. H. (1927). Discussion. In Transactions of the 7th Congress Far Eastern Association of Tropical Medicine. Vol. I, p. 229. Thacker's Press and Directories, Calcutta.

- and Orr, I. M. (1936). Some contributions to the causation, pathology and treatment of duodenal ulcer and its complications. Brit. J. Surg., 24, 227-245.

Wilkie, D. P. D. (1926). Coincident duodenal and gastric ulcer. Brit. med. J., 2, 469-470. 